\title{
Reduced serum free thyroxine concentration in postmenopausal women receiving oestrogen treatment
}

\author{
HOSSAM I ABDALLA, DAVID M HART, GRAHAM H BEASTALL
}

\begin{abstract}
Thyroid hormone state was assessed in a group of postmenopausal women who had received long term treatment with oestrogen. Serum concentrations of total thyroxine, triiodothyronine, and thyroxine binding globulin were raised compared with those in a control group given placebo; serum concentrations of thyroid stimulating hormone did not differ between the groups. Oestrogen treatment resulted in a significant decrease in the serum free thyroxine concentration and in the ratio of thyroxine to thyroxine binding globulin, which supports the view that oestrogen is the causative factor of the physiological reduction in free thyroid hormone during pregnancy.
\end{abstract}

\section{Introduction}

It has long been maintained that free thyroxine and free triiodothyronine represent the biologically active forms of thyroid hormones in plasma and that measurements of these fractions most accurately reflect the true state of the thyroid hormone target issue. Thus the fact that free thyroxine and triiodothyronine concentrations are decreased during pregnancy, a time of increased metabolic rate, is somewhat surprising. ${ }^{1-9}$ Such changes in serum free thyroxine concentrations have not been seen in subjects taking conventional oral contraceptives. ${ }^{2} 410$

In an attempt to establish whether the changes in serum free thyroxine concentrations during pregnancy are related solely to oestrogen or are brought about by some other facet of pregnancy we studied the thyroid state of a group of postmenopausal women who had undergone oophorectomy and were receiving long term replacement treatment with either oestrogen or a placebo.

\section{Patients, methods, and results}

We randomly selected for this study 38 patients who were taking part in a long term study on the effect of mestranol on bone mineral content. ${ }^{11}$ The original allocation to either the active drug or placebo had also been random. Nineteen patients had been taking mestranol $(24 \mu \mathrm{g} /$ day) for a mean of eight years. The other 19 patients were taking placebo tablets with no known effect on endocrine function. None of the patients was suspected of having any thyroid disease, and none was taking any drugs other than mestranol that might influence thyroid function. Table I gives the characteristics of each group.

All subjects donated a fasting blood specimen on the same day. Serum total thyroxine and triiodothyronine concentrations were assayed with solid phase radioimmunoassays. Serum thyroid stimulating hormone concentration was measured with an immunoradiometric assay based on two polyclonal antisera, and serum thyroxine

\footnotetext{
Department of Obstetrics and Gynaecology, Stobhill General Hospital, Glasgow G21 3UW

HOSSAM I ABDALLA, MRCOG, registrar

DAVID M HART, MD, FRCSGLAS, consultant

Department of Biochemistry, Royal Infirmary, Glasgow G4 GRAHAM H BEASTALL, PHD, MRCP, top grade biochemist

Correspondence to: $\mathrm{Mr}$ Hossam I Abdalla.
}

binding globulin concentration with the Corning Immophase kit. Serum free thyroxine concentration was estimated with an analogue binding method (Amerlex; Amersham International).

Student's $t$ test for unpaired data was used to examine the difference in mean values between the two groups.

As expected the serum concentrations of total thyroxine, total triiodothyronine, and thyroxine binding globulin were significantly higher in the group treated with oestrogen compared with the controls (table II). The serum concentration of thyroid stimulating hormone was not significantly different between the two groups. Serum free thyroxine concentrations and the derived ratio of thyroxine to thyroxine binding globulin (an indirect index of free thyroxine) were $18 \%$ and $32 \%$, lower, respectively, in the group given oestrogen compared with the controls (table II).

TABLE I-Characteristics of patients taking active drug (oestrogen) and placebo (values are means $(S D)$ )

\begin{tabular}{|c|c|c|}
\hline & $\begin{array}{c}\text { Active } \\
\text { drug }\end{array}$ & Placebo \\
\hline $\begin{array}{l}\text { Age (years) } \\
\text { Years since menopause } \\
\text { Years taking drug } \\
\text { Height }(\mathrm{cm}) \\
\text { Weight }(\mathrm{kg})\end{array}$ & $\begin{array}{cc}58 \cdot 1 & (4 \cdot 1) \\
12 & (2 \cdot 0) \\
8 \cdot 8 & (1 \cdot 4) \\
159 \cdot 2 & (4 \cdot 8) \\
59 \cdot 46 & (6 \cdot 2)\end{array}$ & $\begin{array}{c}59.2(3.9) \\
11.2(2.8) \\
8.25(0.9) \\
158.9(6.5) \\
63.61(8.4)\end{array}$ \\
\hline
\end{tabular}

TABLE II-Serum thyroid hormone state in patients given active drug (oestrogen) and placebo (values are means $(S D)$ )

\begin{tabular}{|c|c|c|c|}
\hline & Active drug & Placebo & Significance \\
\hline $\begin{array}{l}\text { Total thyroxine (nmol/1) } \\
\text { Total triiodothyronine (nmol/1) } \\
\text { Thyroid stimulating hormone (MU/1) }\end{array}$ & $\begin{array}{r}133 \cdot 2(27 \cdot 4) \\
2 \cdot 72(0 \cdot 4) \\
2 \cdot 99(3 \cdot 6)\end{array}$ & $\begin{array}{r}99 \cdot 6(22 \cdot 3) \\
2 \cdot 22(0 \cdot 4) \\
2 \cdot 91(1 \cdot 6)\end{array}$ & $\begin{array}{c}p<0.001 \\
p<0.001 \\
\text { NS }\end{array}$ \\
\hline $\begin{array}{l}\text { Thyroxine binding globulin (TBG) } \\
\text { (mg/l) } \\
\text { Thyroxine: TBG }(\mu \mathrm{mol} / \mathrm{g}) \\
\text { Free thyroxine }(\mathrm{pmol} / \mathrm{l})\end{array}$ & $\begin{array}{c}47 \cdot 0(9 \cdot 8) \\
2 \cdot 90(0 \cdot 6) \\
15 \cdot 7(3 \cdot 1)\end{array}$ & $\begin{array}{l}24 \cdot 2(6 \cdot 3) \\
4 \cdot 25(1 \cdot 0) \\
19 \cdot 2(2 \cdot 7)\end{array}$ & $\begin{array}{l}\mathbf{p}<0.001 \\
\mathbf{p}<0.001 \\
\mathbf{p}<0.001\end{array}$ \\
\hline
\end{tabular}

Conversion: SI to traditional units-Thyroxine: $77 \cdot 7 \mathrm{ng} / 100 \mathrm{ml}$. Triiodothyronine: $1 \mathrm{nmol} / 1 \approx 0.65 \mathrm{ng} / \mathrm{ml}$.

\section{Discussion}

The significant decrease in the free thyroxine concentration and the derived ratio of thyroxine to thyroxine binding globulin in postmenopausal patients receiving mestranol is in line with previous observations in pregnancy suggesting that the free thyroxine concentration falls in response to an increase in oestrogen rather than to any other facet of pregnancy. The decreased free thyroxine concentration was not a methodological artefact caused by raised concentrations of thyroxine binding globulin as normal free thyroxine concentrations have been found with the same method in patients with congenital excess of thyroxine binding globulin (P G H Byfield et al, unpublished findings presented at meeting of British Endocrine Society, 1983); and it was not specific to the method used as decreased serum free thyroxine concentrations during pregnancy have been found with other methods including equilibrium dialysis. ${ }^{412}$ The reduced free thyroxine concentration in the treatment group did not reflect any degree of hypothyroidism as all the patients were clinically euthyroid and the serum concentration of thyroid stimulating hormone did not differ from that in the control group. Hence the fall in the free thyroxine concentration must be regarded as a physiological response to the oestrogen rich environment. 
There is some evidence to suggest that oestrogen exerts its effect direct on the thyroid gland as replacement treatment with oestrogen reduces release of iodide by the thyroid both in normal subjects and in patients with hypopituitarism treated with a constant dose of thyroid stimulating hormone. ${ }^{13}$ On the other hand, oestrogen may also exert an effect in subjects without functional thyroid tissue as it reduces the consumption of thyroxine by patients being treated for myxoedema. ${ }^{14}$

Oestrogen treatment certainly increases serum concentrations of thyroxine binding globulin, and it is tempting to link this with the observed fall in free thyroxine concentrations in oestrogen rich states. Ekins argued, persuasively, that the free fraction of thyroid hormones in plasma may not be the sole determinant of tissue response and that the concentration of protein bound hormone may also be important in determining the rate of delivery of thyroxine to target tissues. ${ }^{12}$ This hypothesis might explain the reduced free thyroxine concentrations in this study and in pregnancy but would not explain the normal free thyroxine concentrations in cases of congenital excess of thyroxine binding globulin. Possibly, however, oestrogen may affect the rate of delivery of free thyroxine from binding globulin to target tissue.

Franklyn et al suggested that the observed changes in free thyroxine concentration in pregnancy might be explained by an oestrogen induced change in the cellular uptake or nuclear receptor binding of thyroid hormones leading to a compensatory fall in the circulating concentration of free thyroid hormone. ${ }^{3}$ Such a postulate might help to explain the hypermetabolic state associated with pregnancy and also the increase in energy reported by most postmenopausal women receiving oestrogen replacement treatment.

At first sight, the absence of a fall in free thyroxine concentrations in normal women receiving oral contraceptives ${ }^{2410}$ is not consistent with the findings of this study. It is difficult, however, to interpret data in women taking oral contraceptives as they are ingesting progestogen as well as oestrogen and these may have opposing effects on free thyroid hormone state. In addition, most courses of oral contraceptives include one week in which tablets are not taken. Consequently results may vary depending on the timing of sampling during the treatment cycle. Furthermore, these women also have ovaries, which, although their function is suppressed, may still influence thyroid hormone metabolism.
In conclusion, the results of this study show that oestrogen treatment induces a physiological decrease in serum free thyroid hormone concentration in subjects free from the influence of ovaries or the fetoplacental unit.

\section{References}

${ }^{1}$ Boss AM, Kingstone D. Further observation on serum free thyroxine during pregnancy. $\mathrm{Br}$ Med $\mathcal{f} 1981 ; 283: 584$.

${ }^{2}$ Emrich D, Schondube H, Schreivogel I, Schurnbrand P. Pathophysiological and clinical significance of free T4. In: Evans IMA, ed. Free T4, the way ahead in thyroid diagnosis. Oxford: Medicine Publishing Foundation, 1982:1-8.

${ }^{3}$ Franklyn JA, Sheppard MC, Ramsden DB. Serum free thyroxine and free triiodothyroxine concentrations in pregnancy. $B r$ Med $\mathcal{F} 1983 ; 287: 394$.

${ }^{4}$ Helenius $\mathrm{T}$, Liewendahl $\mathrm{K}$. Improved dialysis method for FT4 in serum compared with five commercial radioimmunoassays in non thyroidal illness and subjects with abnormal concentration of thyroxine binding globulin. Clin Chem 1983;29:816-22.

${ }^{5}$ Kurtz A, Dwyer K, Ekins R. Serum thyroxine in pregnancy. $\mathrm{Br} \mathrm{Med} \mathcal{f}$ 1979 ;ii: :550-1.

${ }^{6}$ Midgley JEM, Wilkins TA. The direct estimation of free hormone by a simple radioimmunoassay. Amersham: Amersham International, 1981.

${ }^{7}$ Rootwelt K, Solberg HE. Free thyroxine, thyroxine/TBG ratio and other in vitro tests of thyroid function evaluated by discriminant analysis. Scand $\mathcal{F}$ Clin Lab Invest 1981 ;41:483-91.

${ }^{8}$ Wellby ML, Guthrie L, Reilly CP. Evaluation of a new free thyroxine assay. Clin Chem 1981;27:2022-4.

${ }^{9}$ Hopton MR, Ashwell K, Scott IV, Harrop JS. Serum free thyroxine concentration and free thyroid hormone indices in normal pregnancy. Clin Endocrinol 1983;18:431-7.

${ }^{10}$ Lecureuil M, Reynes GC, Bensard JC, Choffel C. Correlation of FTI and T4:TBG ratio with FT4 concentration as measured by the thyroxine and TBG radioimmunoassays. Clin Chim Acta 1978;87:373-81.

11 Aitken JM, Hart DM, Lindsay R. Oestrogen replacement therapy for the prevention of osteoporosis after oophorectomy. Br Med f 1973;iii :515-8.

${ }^{12}$ Ekins RP. The direct immt noa ssay of free (non protein based) hormones in body fluids. In: Hunter WM, Corrie JET, eds. Immunoassays of clinical chemistry. 2nd ed. Edinburgh: Churchill Livingstone, 1983: 319-37.

${ }^{13}$ Zaninovich AA, Boado R, Uloa E, Bormay NR, Matty AJ. Inhibition of thyroidal iodine release by oestrogen in euthyroid subjects. Acta Endocrinol 1982;99:386-92.

${ }^{14}$ Dowling JT, Freinkel N, Ingbar SH. Effects of diethylstilboestrol on the binding of thyroxine in serum. F Clin Endocrinol Metab 1956;16:1491-6.

(Accepted 4 fanuary 1984)

\section{Food hypersensitivity made life threatening by ingestion of aspirin}

Immediate hypersensitivity reactions to food have been well described. In experimental animals concomitant ingestion of acetylsalicylic acid has been shown to amplify the response, ${ }^{1}$ but this has not previously been documented in man. We report on a boy who was known to develop mild local symptoms of hypersensitivity to peanuts but who developed a life threatening hypersensitivity reaction after ingesting peanuts in combination with aspirin.

\section{Case report}

The patient was a 14 year old boy who had suffered from eczema, asthma, and hay fever since early childhood. His eczema and asthma were exacerbated by contact with cats and dogs, and asthma was also induced by drinking orange squash. His asthma was generally mild. He was taking disodium cromoglycate by inhaler (Spinhaler) twice daily and salbutamol by inhaler as required. He had eaten food containing peanuts on three occasions since the age of 2 and had experienced an identical reaction each time. The reaction started within seconds and was characterised by tingling and dryness of the lips and mouth followed by swelling of the lips and face with a sensation of choking in the throat. Signs and symptoms always passed within five minutes. He had taken aspirin on several previous occasions with no ill effects.

On the day of admission he had had a mild headache, for which he took two $300 \mathrm{mg}$ tablets of soluble aspirin. Five minutes later he had eaten a piece of cake containing peanuts. He suffered his usual reaction to peanuts and within five minutes was perfectly well. Thirty minutes after eating the cake he became unwell with generalised pruritus, a choking sensation, and extreme shortness of breath, and then he collapsed. On admission to hospital he was unconscious, deeply cyanosed, and covered with an urticarial rash. Pulse rate was 120 beats/minute, and blood pressure was $120 / 80 \mathrm{~mm} \mathrm{Hg}$ with arterial paradox of $40 \mathrm{~mm} \mathrm{Hg}$. Breath sounds were very quiet, and there was little wheeze. Blood gas analysis showed $\mathrm{pH} 6.85$, carbon dioxide pressure $14.7 \mathrm{kPa}(110 \mathrm{~mm} \mathrm{Hg})$, oxygen pressure $5.5 \mathrm{kPa}(41 \mathrm{~mm} \mathrm{Hg})$, and base excess $-19 \cdot 3 \mathrm{mmol}(\mathrm{mEq}) / \mathrm{l}$. Electrocardiography showed atrial ectopic beats with periods of sinus arrest. He was given intravenously $0.5 \mathrm{ml}$ of $0.1 \%$ adrenalin solution, $50 \mathrm{ml}$ of $8.4 \%$ sodium bicarbonate solution, $150 \mathrm{mg}$ aminophylline, $100 \mathrm{mg}$ hydrocortisone, and $5 \mathrm{mg}$ chlorpheniramine. He made a dramatic recovery and within 10 minutes was conscious with mild wheeze and arterial paradox of $25 \mathrm{~mm} \mathrm{Hg}$. Forty five minutes after admission he was completely asymptomatic, and he remained well thereafter.

\section{Comment}

Animal experiments have shown that aspirin greatly increases the permeability of the gastric mucosa to plasma proteins and that this 